\title{
Anthós
}

\section{"The Revolutionary Road to Ruin: Friedrich Hecker and the Insurrection of April 1848": An Interview with Dr. Steven Fuller (Department of German, Portland State University) About his Upcoming Book}

Alex Sorenson

Portland State University

Follow this and additional works at: https://pdxscholar.library.pdx.edu/anthos

Part of the European History Commons

Let us know how access to this document benefits you.

\section{Recommended Citation}

Sorenson, Alex (2012) "'The Revolutionary Road to Ruin: Friedrich Hecker and the Insurrection of April 1848": An Interview with Dr. Steven Fuller (Department of German, Portland State University) About his Upcoming Book," Anthós: Vol. 4: Iss. 1, Article 8.

https://doi.org/10.15760/anthos.2012.118

This open access Article is distributed under the terms of the Creative Commons Attribution-NonCommercialShareAlike 4.0 International License (CC BY-NC-SA 4.0). All documents in PDXScholar should meet accessibility standards. If we can make this document more accessible to you, contact our team. 
“The Revolutionary Road to Ruin: Friedrich Hecker and the Insurrection of April 1848”: An interview with Dr. Steven Fuller (Department of German, Portland State University) about his upcoming book

Interview and Transcript by Alex Sorenson (3/14/2012)

AS: What is the subject of your book?

SF: What I'm trying to follow is an insurrection led by Friedrich Hecker from April $12^{\text {th }}$ to April $20^{\text {th }}$ in 1848 that was expecting an avalanche of support and revolution to grasp Germany, but completely failed.

AS: When and how did the project originally emerge?

SF: Well, about ten years ago I had basically had my fill of studying the Nazis and National Socialism, which is sort of the pornography of intellectual history. And while, like pornography, that's interesting on one level, it's also brutalizing; it does violence to you as you study it. So after twenty-five years of this, I wanted to try to study something that was a bit more idealistic, and the proto-socialist thinkers at the turn of the nineteenth century is where I ended up. Certainly more idealistic and Romantic than the Nazis!

AS: Where did your idea for the book come from?

SF: It really started with the idea of looking at the "myth" of America in the revolution. Initially, the project that I was involved in was to write the story of the revolutionaries from 1848 who were forced to go into exile and come to America. This is the story that I eventually want to tell, but what I came upon first was this initial story, which was a great compact narrative of a tenday journey made by Friedrich Hecker from Konstanz up into the Black Forest and back down to Basel that I felt I could use to talk about the entire revolution. The story of Friedrich Hecker becomes a sort of metaphor within European history for the failed revolution. This phrase "failed revolution" really seems to fall trippingly from the tongue in the West. So I found the project within a larger project that I want to do on this side of the Atlantic, but I felt that I had to first explore this earlier story on the other side of the Atlantic.

AS: What do you find to be especially significant about Friedrich Hecker as an historical figure? SF: Hecker was demonized by his opponents and also made into a saint by his supporters, and eventually went to America himself. I wanted to write about this story of a failed German revolutionary who, along with five thousand other failed German revolutionaries, goes to America and re-invigorates the American political and economic process at mid-century shortly before the Civil War. All of these people from the revolution of 1848 went on to fight in the American Civil War, and fifteen of them ended up becoming generals in the Union Army. So all of these Germans, who were strangely enough called "the Dutchmen", were a decisive factor in the war. This was the story I originally wanted to tell, but I became interested in looking back a 
bit earlier, and especially at the story of Hecker. Even though the 1848 insurrection was relatively small (only involving a few thousand men on both sides), conservatives saw Hecker as a paradigmatic symbol for the failed revolution. He was a kind of boogeyman, and they used this small battle that he fought in the foothills of Basel as a metaphor for the idea of failed revolutionary and violent change, or even that the attempt to change society in any dramatic way will always end in failure. They were trying to convince people that a more moderate course was the best way to go, and they eventually attempted later in the revolution (1848-49) to take such a moderate course, which also failed. People often say that Hecker was wrong, but Hecker wasn't wrong-in fact he was probably right. It's said of him either that he came too early or came too late.

AS: How did you approach the project (what sorts of research did you do for it, how did you go about writing it)?

SF: In terms of my scholarship, it was very difficult because I wasn't doing the period immediately before the Nazis (my original area of expertise) nor the period immediately after, but was really looking at two periods before. So it took me about a decade to give myself enough background, to learn the period from 1800 to 1848 as well as the period after 1848 in order to get a sense of where I was placing myself intellectually. That was a major task, just the vast amounts of reading. Also, this is not a literary subject per se; there are reflections of it within literature, but this is an historical project. It is also partially biographical. I love biography and individual stories, the "story" of history, the "Geschichte" of Geschichte. ${ }^{1}$ However, I'm really building this around a literary model and trying to write a kind of history that lets various voices speak at the same time, not a biography that lionizes Hecker or makes him into a hero. This is something that I'm very clear about not wanting to do. I want Hecker to be a vehicle that lets other voices from the far Right to the far Left speak about him, and to let the reader make decisions about what they think of Hecker and the revolution, or about revolution in general.

AS: Isn't there a partial autobiographical aspect of the study as well?

SF: Yes, and that's a part of this that I could not have imagined happening. I studied this and did the background reading for ten years, and then I went to Germany to work in the archives, libraries, and museums to trace the trail of these ten days in 1848, to document the exact route of Hecker's journey, which is something that has never been done. And I ended up deciding that I was going to actually walk it, to walk the journey on exactly the same days that Hecker had, and then something happened that was very quixotic-one might even say psychadelic. I was in the same places, literally walking the same pieces of ground that Hecker had on the very same day, though admittedly a hundred and sixty-five years earlier than me. Yet all of a sudden when I began to write and journal as I was traveling, I would walk into a town and be able to say "we walked into town at four o'clock in the afternoon". Then what happened more and more is that my own story began to project itself into the nineteenth century, and the nineteenth century began to project itself into the twenty-first century. The people I was meeting and the villages I

\footnotetext{
${ }^{1}$ Geschichte means both "story” and "history” in German.
} 
was walking through were of course changed, but they were also not changed. That landscape is five thousand years old, it's a cultural landscape, and these villages that I passed through were at least one thousand years old, so in many ways a given village has a longer and stronger historical continuity than the discontinuity between Hecker and myself one hundred and sixty-five years later. I was staying in the same hotels and eating in the same restaurants that he did because they're still there. I have many memories of meeting country people living in these tiny places who were trying to get out of their rural village and make a future for themselves. I would meet a group of teenagers as I walked into a town and think to myself that this would have been a group of teenagers that would have followed Hecker. Then they'd tell me their own stories and I was able to project them back one hundred and sixty-five years and think "these are the same people, basically”. They were historically different, and culturally somewhat different, but in a similar situation, and in a village that's one thousand years old they certainly have more in common with me and with Hecker than they do with the Baroque period or the Renaissance or the Middle Ages.

And so that development of a quixotic projection of myself into the revolution and of the revolution into my own story led to me beginning to write much more of a first-person narrative, and I use this in the book as a kind of touchstone, of bringing it back to me in the present. I found I was writing a lot about this present-day section of Germany (Baden) that is still incredibly vibrant and being able to see the continuities between what Hecker was proposing and the people, the economy, and the landscape that is essentially still the same. This is a subjective side of history, but it isn't so subjective that it's a novel, even though it does take on certain features of fiction.

One other thing I'd like to mention is that I took my daughter with me, and while she didn't go on the actual walk, she and I spent two months tracing the route in a car, going to every library and revolutionary tavern. It was interesting to notice her impressions of what we were seeing, being from a different generation than I, and her ability to see things in a different way. People of my generation have a tendency to blend our aesthetic tastes and our political biases together, and I think your generation is much better at separating out those moments-not necessarily to see them as different, but to separate them. She and I would get into lots of conversations about my liking a particular building because I enjoyed the political project that it represented (e.g., Karl Friedrich Schinkel and Classicism), and she would then point out how my politics were getting in the way of my aesthetic judgment. So my daughter proved to be a certain source of wisdom for me throughout the trip, and doing the research, location scouting, and smaller walks within the larger walk with her gave me a generational take on everything that I would have never gotten otherwise. She appears in the book as a character time and time again, and another character is my own mentor from Berlin who taught me everything, and is of yet another generation.

AS: How does the autobiographical mode you partially employ inform or interact with the more traditional historiographical aspects of your study?

SF: They do reflect back on each other, and I feel that they flow together very nicely as well. I'm 
slightly fearful that traditional historians will find the first-person narrative to be self-indulgent, and that people who are reading the book more as a popular history will find the historical detail to be pedantic, that it's sort of caught between genres. But that's exactly what I'm trying to write: I'm not trying to write historical fiction, instead in many ways I'm trying to write fictional history. In the book there's a lot of speculation and projection about what "must have had happened", a sort of subjunctive use of modal verbs, in that I deduce from being on the ground. There are obviously certain aspects of betting my own academic career on this project in the same way that Hecker was betting his political career on the revolution.

So, I found this voice fairly quickly and in a strong way, and became committed to it on the journey, and that's something that I could not have predicted if I hadn't walked, if I had stayed in the libraries and archives. Traditional historiography has always been done from the "inside", from inside the library and inside the archive. In my mind that is a view from above that attempts to create an "Olympian" history where the historian is looking down as a sort of puppetmaster, moving pieces around and trying to understand what is going on in a larger sense. My study does this, but it is also a history written from below, from the ground, and literally from the landscape.

AS: How would you distinguish this "boots on the ground" method for writing history from similar historiographical approaches to a given topic through a specific lens, such as a particular figure, location, etc.?

SF: I'm trying to identify not with the person but with the journey. In a study like this, you're identifying as much with the revolutionaries as you are with "the figure" per se. In this case, I walked thirty-five miles a day in the same way that Hecker's men walked thirty-five miles a day, and so my task was to not have this be an individual memoir that relates everything from the position of the hero. Instead, I try to tell everything from below, from the position of the participants in the journey, which is very different. I also think an approach that's done from the "outside" and "underneath" makes history much more compelling than one from "inside" and "above". Traditional history has done the latter much more than the former. This study is from the perspective of the physical, and is much more bodily-literally walking the journey, tasting it, smelling it, sleeping it-as opposed to staying inside the archive. Obviously one cannot be done without the other or else it turns into travel literature, and that's what I'm afraid of but also most excited about: that this is in between genre. This is not traditional history, nor is it travel literature. It's some sort of hybrid in between.

AS: Are there any precedent studies employing this method that have been influential for your own work?

SF: I think something like The Devil in the White City [Erik Larson, Vintage 2003], which is about the Chicago World's Fair and is blended in with a true story that's also a kind of fictionalized-history version of a mass murderer. That's one book that affected me a lot, and displays the basic idea of what I'm trying to do on the level of a monograph. Also David Blackbourn's The Conquest of Nature [W.W. Norton and Co. 2006], which is about water and 
landscape and the re-molding of the land in Germany. One thing I attempt in my own project is to "re-claim" landscape for history. I do think that this is being done, and writing about landscape has a notorious past in the German tradition, but the idea in Blackbourn's book of looking at landscape as cultural landscape is something that had a big effect on me. Also in his study is the attempt I mentioned earlier to let the various voices speak for themselves, and to present not a singular narrative of history but a set of voices that are speaking to the reader.

AS: Having just finished writing about political and social revolutions in nineteenth-century Europe, how do you regard the uprisings and revolutions that have recently occurred in the United States, the Middle East, and elsewhere?

SF: [My field research for this project] took place during the Arab Spring, which is something that I could not possibly have known about after planning this for ten years. It seems to me that there has always been a paradigm where we in the West look at the East and take a paternalistic attitude - that they're less developed than we are, that they have things to learn from us - when in fact the opposite is true. The European attempt at an Arab Spring in 1848 (the so called Spring of Peoples, Spring of Nations) ultimately failed, and freedom didn't really come until the next century. So it sort of reverses a political paradigm, where we in fact don't have anything to teach them about revolution and popular political change, and ours is a tradition of failed revolution.

AS: Have you read any monographs or studies by other scholars over the last year that you're especially excited about?

SF: Blackbourn's book, really. Mostly in terms of his ability to create a non-dogmatic history while at the same time documenting it and coming to conclusions, and also in terms of his way of looking at European landscape. Landscape has traditionally been regarded as a sort of wilderness that represents nature, whereas in Europe that simply doesn't exist. It's been a cultural landscape for five thousand years that has been molded by people and human efforts, so the study of landscape is also the study of Sociology at the same time. Conversely, in America the land is wilderness and Manifest Destiny, and takes on a sort of a priori characteristic. In Europe that would be a lie, a myth. So what I think Blackbourn's book does is to say that landscape is an historical, sociological, cultural category.

AS: Are there any other potential future projects that you might want to approach using the method of your current study, or do you think this is more of a one-time thing?

SF: No, I definitely have others in mind. For instance, while in Germany I walked through a particular valley where a very famous Nazi came from (Albert Leo Schlageter), and I thought how doing this study about a romantic revolutionary from the nineteenth century is pretty accepted historically. Then I wondered "what if I were to take a single day in the history of November 1923 and to walk the streets of Munich with Hitler?” How would that be if I wasn't doing it for a hero but essentially for a villain? So I do think there are these little historical "walks" that are very interesting for telling the narrative of Hitler's attempted beer-house coup 
d'état in 1923 by walking from the Hofbräuhaus to the ministry of defense and to then find out where the rest of them went at that same time. Also to document what is still there, what's not there, which buildings [Hitler] walked by, which are new since then, and to then use this walk as a means for a history that's not synchronic but that is diachronic. That is, one that doesn't take place at a single time and a single place, but one that moves back and forth from the present to the past and vice versa, because history is a story that is only really pertinent if it informs and is informed by the present. It's this idea of writing a critical history instead of a monumental history, or the purely pedantic, antiquarian history. [If you place too much emphasis on] the past instead of the present and on narrative, history doesn't come across as being determined. Of course, things happen in the past and happen in a certain way based upon a certain set of contingencies. However, if you tell that history in a way that combines the present and the past, it opens up the possibilities of change and revolution for the present. I think that is the larger task. 